\title{
Bodies of Emotion: Rethinking Culture and Emotion through Southeast Asia
}

\author{
Feelings are not substances to be discovered \\ in our blood but social practices organized \\ by stories that we both enact and tell. \\ MICHELLE ROSALDO I984:I43
}

\section{Tom Boellstorff \& Johan Lindquist}

University of California, Irvine, USA/Stockholm University, Sweden

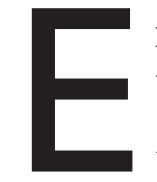

motion has represented a tantalizing subject for social scientific inquiry because it appears to tell us about our true selves; the self that, after all the thinking and interacting are done, feels the welling-up of rage, the tender pangs of love, the black emptiness of despair. Invoking methodological individualism, our phrasing here frames emotions as the property of persons, and indeed the majority of research on emotion has assumed that the individual experience of emotion is fundamentally prior to its social experience, its so-called 'context.' In this tradition (see Lutz \& White 1986 for an overview and critique), emotion's location in culture is acknowledged in broad terms. An example of this is the notion of an 'emotion lexicon' drawn upon by persons from a 'cultural group,' where the latter term means 'speakers of the same language.' Languages (almost always authorized national languages) stand in for culture, and researchers discover that all speakers of a language share a cognitive structure for emotion (Kovecses I990, 2000; Wierzbicka I999). Difference is downplayed; for instance, a recent questionnaire-based social psychological study of gender and emotion 'found the anticipated effects of sex of respondent with respect to all three aspects of emotion (intensity, duration, and expression), showing that women in all countries reported more intense emotions, and of a longer duration, and that they also expressed their emotions more overtly' (Fischer \& Manstead 2000:88).

The dominant social psychological approach thus pairs a methodological individualism with a theoretical universalism, and 'culture' - that historically specific mediating level as fundamental to human experience as 'English,' 'Thai,' or 'German' - is elided. This approach continues to this day in research on emotion in Southeast Asia (the areal focus of the present collection), and can justly claim to have significantly broadened our understanding of lexicons 
for emotion. Its abstracted understanding of emotion, however, leads to a range of errors. These range from the minor (like the difficulties of translating the key Indonesian term hati, which means both 'liver' and 'seat of the emotions' and is thus sometimes rendered as 'heart' (Shaver et al. 200r:206)), to the more general issue of assuming that 'within a cultural group, the cognitive structure of emotions can be conceptualized as the cognitive representation of differences and similarities between emotion terms' (Fontaine et al. 2002). This viewpoint is grounded in a referential view of language where emotions 'are treated, through the process of reification, not as concepts used to do certain kinds of things in the world but as labels for concretized psychophysical states or objectivized internal "event-things"' (Lutz I988:9).

The ultimate goal of this volume is to further develop analyses that treat emotion as cultural - and culturally specific - without ontologizing either the individual or social. It is to recognize that the dogged persistence of the individual/social binarism, despite longstanding and creative efforts to deconstruct it, is more than an intellectual fillip. It reveals deeply held assumptions (and not just Western ones) about the relationship between embodied versus transpersonal modes of being. Developing theoretical and methodological tools to prise open the individual/social binarism still stands as an important frontier in social inquiry. In his Epilogue to this volume, Byron Good notes that when this binarism is mapped onto a disciplinary divide between psychology and anthropology, anthropologists potentially deny themselves the insights of thinkers ranging from Jacques Lacan and Frederic Jameson to Wendy Brown and Judith Butler. Taking seriously the 'kinship' of these thinkers with anthropology (Strong 2002) has much to offer our discipline. We hope that placing this set of articles into the context of an earlier period of interdisciplinary conversation concerning emotion and culture will suggest some ways in which this dialogue can be rejuvenated and transformed in the current moment without compromising a commitment to an ethnographic approach that considers long-term fieldwork critical to the study of emotions.

We develop our analyses through a series of investigations of contemporary Southeast Asia, which since the I970s has become a key area for anthropological discussions of bodily and emotional control. This was exemplified primarily through the work of Clifford Geertz (I973) and later Michelle Rosaldo (1980, 1983, I984), who positioned the study of emotions squarely in the context of cultural analysis. Geertz's version of interpretive anthropology rethought the relationship between individual and social in the realm of emotion. 
'Not only ideas,' he wrote, 'but emotions too, are cultural artifacts' (I973:8I). Rosaldo claimed that 'affects, then, are no less cultural and no more private than beliefs' (I984:I4I). In other words, emotions were not to be analyzed outside of the social and cultural context in which they were experienced, understood, and talked about. However, both Rosaldo and Geertz grounded their studies in ethnographic contexts in which culture, ethnicity, and language were relatively isomorphic. Such conceptual wholes were increasingly problematized in American cultural anthropology during the r980s and r99os, due both to the increasing (and increasingly apparent) impact of globalizing processes and theoretical critiques of the culture concept (Clifford \& Marcus I986; Keesing 1987). In more recent years, an increasing focus on globalization and transnational processes has led to an interest in problematizing the relationship between 'culture' and 'place' (Gupta \& Ferguson 1997), while the Foucauldian turn in anthropology has shifted attention away from meaning to effects (Ortner I997:I37). Similarly, the increasing interest in the links between anthropology and history has increasingly led to a problematization of the stability of cultural forms (Pemberton 1994).

A renewed attention to the link between emotion and power is evident in work like that of Scheper-Hughes (I992), who has been explicitly concerned with the political economy of emotions in her work on nervios in Brazilian shantytowns, and Good, Good, and Fischer (1988), who have shown how the Iranian state has been engaged in organizing public expression of emotions. While Geertz and Rosaldo worked in what were understood to be relatively homogenous cultures, anthropologists must now directly address issues related to nationalism and globalization. Nationalism is perhaps the most obvious example of how affect is organized within decidedly non-local communities (Anderson I983), and this raises important questions concerning the role of the state and mass media in transforming subjectivities and emotional landscapes. Similarly, globalization theorists have argued that the mobility of people and media images are crucial in theorizing transnational processes (Appadurai I996, Hannerz I996). Increasing domestic and transnational migration throughout Southeast Asia, for instance, destabilizes notions of clearly circumscribed cultural forms.

We return to Geertz and Rosaldo to acknowledge their groundbreaking work in the ethnography of emotion. In place of a stance of dismissal, contributors to this issue of Ethnos return to Southeast Asia at the dawn of the new millennium to ask: How can this work be rethought in the contemporary context? How do the solidification of postcolonial nationalisms on the one

ETHNOS, VOL. 69:4, DEC. 2004 (PP. 437-444) 
hand, and globalizing forces on the other, compel us to transform this important theoretical and ethnographic legacy? What are the implications of such a reconfiguration for discussions of emotion in anthropology more generally? A key issue for us concerns the relationship between the body and emotion. In recent years, particularly under the influence of work inspired by feminist, Foucauldian, and critical medical anthropological frameworks (which are, of course, not mutually exclusive), 'the body' has become a near-panacea for anthropology's ills (see Scheper-Hughes \& Lock I987). Attention to the body, it seems, holds the promise of grounding our work in 'the real world' against overly cognitive or ideational perspectives. The danger is that 'the body' can become an inadvertent rallying point for a reworked methodological individualism (see Lyon I995) unless its fundamentally social character, so often de-emphasized in 'Western' traditions, is foregrounded instead (ScheperHughes \& Lock 1987). The contributors to this volume, while (as is always the case) diverse in theoretical and methodological approaches, share a commitment to ethnographic understandings of emotion as embodied yet foundationally social.

Taken as a whole, we thereby acknowledge the wide range of work on body and emotion in Southeast Asia, from the performance of political power (Anderson 1990; Barker 1998) to the expression of shame (Geertz I973; Rosaldo I983; also Collins \& Bahar 2000; Errington I989; Heider I991; Hollan \& Wellenkamp 1994; Keeler 1987; Wikan r990; Cannell 1999), as well as a wide-ranging attention to group violence (most clearly expressed in the Malay/ Indonesian concept of amok, a theme that has become especially pertinent in the wake of recent events in Indonesia) (e.g. Rosaldo I989; Winzeler 1990; Ileto I979). Of particular interest in this context is the implicit juxtaposition between emotionlessness and hyper-emotionality in much of the work dealing with emotions in Southeast Asia (e.g. Lewis I990:v). The contributors to this issue are concerned with both interrogating and moving beyond these juxtapositions, in order to explore how emotional discourse and experience are organized and articulated in contemporary Southeast Asia.

The contributions use emotions as a way of thinking about the anxieties that cultural, economic, and political change generates in the lives of people living in contemporary Southeast Asia. The 'Asian economic crisis' that began in 1997 with the fall of the Thai baht forms the ethnographic backdrop for the majority of the articles; though this 'event' varied from place to place, it had dramatic effects on the lives of most people living in the region. In Indonesia, the effects proved to be particularly widespread, eventually leading to 
kristal (short for krisis total or 'total crisis') and contributing to the downfall of President Suharto. In line with our broader theoretical interests, focusing on emotions in the context of these changes provides us with a way to link social transformation with individual experience. In turn, this ethnographic and historical specificity allows us to destabilize any understanding of emotions as coherent entities that can be isolated from their sociocultural contexts. Southeast Asia at one time was crucial in the formation of an anthropological canon concerning the study of culture and emotion; it remains an area that is 'good to think with' in relation to theoretically innovative approaches to this same topic.

Individual contributions to this special issue combine close ethnographic analyses of emotion with broader concerns about emotion as a culturally embedded phenomenon that brings together domains usually set apart as 'intimate' versus 'public' or 'embodied' versus 'symbolic.' Issues addressed by the contributors include mass media, migration, the social construction of 'place,' and the relationship between gender, sexuality, and the emoting body. These interests reflect the increasingly complicated methodologies employed by anthropologists. Contributors in this issue do not only engage in participant observation together with informal conversations and formal interviews, but also approach emotion through magazine and newspaper articles, and television shows, in order to tease out the circulation of emotional concepts not only in intersubjective relationships, but in the context of market and state power.

There are also various links between the different articles. Boellstorff argues that the new forms of violence against gay men must be understood in relation to the troubled forms of civil society that have emerged during the post-Suharto era. At the heart of his discussion is the widely discussed concept, malu, meaning approximately shame or embarrassment, and the normative male response to this particular emotion, namely aggression. Lindquist's article focuses even more explicitly on malu in the lives of female Indonesian migrants. In this context, he problematizes withdrawal as the proper gendered response to malu by showing how veiling and the drug 'ecstasy' become techniques that allow female factory workers and prostitutes to deal with this complex emotion. Jones' article also focuses on the lives of women, more specifically middle-class Javanese women who must deal with the stres of modern life in the context of the domestic sphere. Jones argues that what she terms the 'emotional labor' of women has been inflected by state rhetoric on gender propriety and market ideas of work. Klima, in his article on post-crash Thailand, 
is similarly interested in the political economy of emotions, particularly the emotions that are generated by nationalist oriented Buddhist donation ceremonies. More generally, he attempts to understand these processes in relation to global systems of capitalist power, rather than in relation to localized cultural systems. Finally, in the epilogue, Good articulates some of the current problems and ways forward in the study of emotions in Southeast Asia and beyond.

\section{Acknowledgments}

This special issue of Ethnos is based on a panel organized by Tom Boellstorff and Johan Lindquist at the 200I Annual Meeting of the American Anthropological Association in Washington D.C. The articles, except the one by Alan Klima, were first presented there. We would like to thank the other participants on the panel for helping us think through many of the themes in this issue. They are Joshua Barker, Shelly Errington, Steve Ferzacca, Thamora Fishel, Kenneth George, Karl Heider, and Smita Lahiri.

\section{References}

Anderson, Benedict. 1983. Imagined Communities: Reflections on the Origin and Spread of Nationalism. London: Verso.

-. I990. The Idea of Power in Javanese Culture. In Language and Power: Exploring Political Cultures in Indonesia. Ithaca, NY: Cornell University Press.

Appadurai, Arjun. 1996. Modernity at Large: Cultural Dimensions of Globalization. Minneapolis: University of Minnesota Press.

Barker, Joshua. 1998. State of Fear: Controlling the Criminal Contagion in Suharto's New Order. Indonesia, 66:7-44.

Cannell, Fenella. 1999. Power and Intimacy in the Christian Philippines. Cambridge: Cambridge University Press.

Clifford, James \& George Marcus (eds). I986. Writing Culture: The Poetics and Politics of Ethnography. Berkeley: University of California Press.

Collins, Elizabeth Fuller \& Ernaldi Bahar. 200o. To Know Shame: Malu and Its Uses in Malay Societies. Crossroads: An Interdisciplinary Journal of Southeast Asian Studies, I $4(\mathrm{I}): 35-69$.

Errington, Shelly. 1989. Meaning and Power in a Southeast Asian Realm. Princeton: Princeton University Press.

Fischer, A.H. \& A.S.R. Manstead. 2000. The Relation between Gender and Emotions in Different Cultures. In Gender and Emotion: Social Psychological Perspectives, edited by A.H. Fischer, pp. 7I-94. Cambridge: Cambridge University Press.

Fontaine, Johnny R.J., Ype H. Poortinga, Bernadette Setiadi, \& Suprapti S. Markam. 2002. Cognitive Structure of Emotion Terms in Indonesia and the Netherlands. Cognition and Emotion, I6(I):6I-86.

Geertz, Clifford. 1973. The Interpretation of Cultures. London: Fontana Press.

Good, Mary-Jo DelVecchio, Byron J. Good, \& Michael J. Fischer. I988. Introduction: Discourse and the Study of Emotion, Illness and Healing. Culture, Medicine, and Psychiatry, I2:I-7.

Gupta, Akhil \& James Ferguson. 1997. Discipline and Practice: 'The Field' as Site, 
Method, and Location in Anthropology. In Anthropological Locations: Boundaries and Grounds of a Field Science, edited by Akhil Gupta \& James Ferguson. Berkeley: University of California Press.

Hannerz, Ulf. 1996. Transnational Connections: Culture, People, Places. London: Routledge.

Heider, Karl G. 1991. Landscapes of Emotion: Mapping Three Cultures of Emotion in Indonesia. Cambridge: Cambridge University Press.

Hollan, Douglas W. \& Jane C. Wellenkamp. 1994. Contentment and Suffering: Culture and Experience in Toraja. New York: Columbia University Press.

Ileto, Reynaldo Clemena. I979. Pasyon and Revolution: Popular Movements in the Philippines, I840-r9ro. Manila: Ateneo de Manila University Press.

Keeler, Ward. 1987. Javanese Shadow Plays, Javanese Selves. Princeton: Princeton University Press.

Keesing, Roger M. 1987. Anthropology as Interpretive Quest. Current Anthropology, 28(2):I6I-I76.

Kovecses, Zoltan. 1990. Emotion Concepts. New York: Springer-Verlag.

- 2000. Metaphor and Emotion: Language, Culture, and Body in Human Feeling. Cambridge: Cambridge University Press.

Lewis, I.M. 1990. Preface. In Emotions of Culture: A Malay Perspective, edited by Wazir Jahan Karim. Singapore: Oxford University Press.

Lutz, Catherine. 1988. Unnatural Emotions: Everyday Sentiments on a Micronesian Atoll and Their Challenge to Western Theory. Chicago: University of Chicago Press.

Lutz, Catherine \& Geoffrey M. White. 1986. The Anthropology of Emotions. Annual Review of Anthropology, 15:405-36.

Lyon, Margot L. 1995. Missing Emotion: The Limitations of Cultural Constructionism in the Study of Emotion. Cultural Anthropology, ro(2):244-263.

Ortner, Sherry B. 1997. Thick Resistance: Death and the Cultural Construction of Agency in Himalayan Mountaineering. Representations, 59:135-162.

Pemberton, John. I994. On the Subject of 'Java.' Ithaca: Cornell University Press.

Rosaldo, Michelle Z. 1980. Knowledge and Passion: Ilongot Notions of Self and Social Life. Cambridge: Cambridge University Press.

-. I983. The Shame of Headhunters and the Autonomy of the Self. Ethos, II(3): I35-5 I.

-. I984. Toward An Anthropology of Self and Feeling. In Culture Theory: Essays on Mind, Self, and Emotion, edited by Richard A. Sweder \& Robert A. LeVine. Cambridge: Cambridge University Press.

Rosaldo, Renato. 1989. Introduction: Grief and a Headhunter's Rage. In Culture and Truth: the Remaking of Social Analysis. Boston: Beacon Press.

Scheper-Hughes, Nancy. 1992. Death Without Weeping: The Violence of Everyday Life in Brazil. Berkeley: University of California Press.

Scheper-Hughes, Nancy \& Margaret M. Lock. 1987. The Mindful Body: A Prolegomenon to Future Work in Medical Anthropology. Medical Anthropology Quarterly, $I(I): 6-4 I$.

Shaver, Phillip R., Upekkha Murdaya \& R. Chris Fraley. 200r. Structure of the Indonesian Emotion Lexicon. Asian Journal of Social Psychology, 4:20 I-24.

Strong, Thomas. 2002. Kinship Between Judith Butler and Anthropology? A Review Essay. Ethnos, 67(3):40I-4I8.

ETHNOS, VOL. 69:4, DEC. 2004 (PP. 437-444) 
Wierzbicka, Anna. I999. Emotions Across Languages and Cultures: Diversity and Universals. Cambridge: Cambridge University Press.

Wikan, Unni. I990. Managing Turbulent Hearts: A Balinese Formula for Living. Chicago: University of Chicago Press.

Winzeler, Robert. I990. Amok: Historical, Psychological, and Cultural Perspectives. In Emotions of Culture: A Malay Perspective, edited by Wazir Jahan Karim. Singapore: Oxford University Press. 